\title{
Olpidium gregarium, a chytrid fungus affecting rotifers populations in Rio Grande Reservoir, São Paulo State, Brazil
}

\author{
Patrícia do Amaral Meirinho ${ }^{1,4}$, Paula Yuri Nishimura ${ }^{1}$, Carmen Lidia Amorim Pires-Zottarelli², \\ Viviane Mochini-Carlos ${ }^{3}$ \& Marcelo Luiz Martins Pompêo ${ }^{1}$ \\ ${ }^{1}$ Departamento de Ecologia, Instituto de Biociências, Universidade de São Paulo - USP, \\ CEP 05508-090, São Paulo, SP, Brasil \\ ${ }^{2}$ Núcleo de Pesquisa em Micologia, Instituto de Botânica, Secretaria do Meio Ambiente, \\ CEP 04045-972, São Paulo, SP, Brasil \\ ${ }^{3}$ Departamento de Engenharia Ambiental, Universidade Estadual Paulista - UNESP, \\ CEP 18087-180, Sorocaba, SP, Brasil \\ ${ }^{4}$ Corresponding author: Patrícia do Amaral Meirinho, e-mail: patymeiri@ib.usp.br
}

MEIRINHO, P.A., NISHIMURA, P.Y., PIRES-ZOTTARELLI, C.L.A., MOCHINI-CARLOS, V. \& POMPÊO, M.L.M. Olpidium gregarium, a chytrid fungus affecting rotifers populations in Rio Grande Reservoir, São Paulo State, Brazil. Biota Neotrop. 13(1): http:/www.biotaneotropica.org.br/v13n1/en/abstract?shortcommunication+bn00913012013

Abstract: A chytrid fungus Olpidium gregarium was found in Rio Grande Reservoir as rotifers populations' parasite. Along the reservoir central axis, the rotifers density decreased in the dam direction, while the density of affected rotifers by the chytrid fungus increased in the same direction. Moreover, some rotifers species were more affected than others, thus showing certain preference for some rotifers species. Thereby, this parasite may be interfering in the distribution of rotifers population in Rio Grande Reservoir. This is the first report of this species for Brazil.

Keywords: parasite, Chytridiomycota, Rotifera, zones.

MEIRINHO, P.A., NISHIMURA, P.Y., PIRES-ZOTTARELLI, C.L.A., MOCHINI-CARLOS, V. \& POMPÊO, M.L.M. Olpidium gregarium, um quitridiomiceto afetando populações de rotíferos no Reservatório Rio Grande, Estado de São Paulo, Brasil. Biota Neotrop. 13(1): http://www.biotaneotropica.org.br/v13n1/pt/ abstract?short-communication+bn00913012013

Resumo: O quitridiomiceto Olpidium gregarium foi encontrado no Reservatório Rio Grande parasitando diversas espécies de rotíferos. Ao longo do eixo central do reservatório, a densidade de rotíferos diminuiu em direção à barragem, enquanto que a abundância relativa de rotíferos afetados pelo quitrídio aumentou na mesma direção. Além disso, algumas espécies de rotíferos foram mais afetadas do que outras, mostrando com isso certa preferência por algumas espécies de rotíferos. Desta forma, este parasita pode estar afetando a distribuição das populações de rotíferos no reservatório. Este é o primeiro relato da espécie no Brasil.

Palavras-chave: parasita, Chytridiomycota, Rotifera, zonas. 


\section{Introduction}

Rotifers are an important part of the freshwater zooplankton, notably the most abundant and diverse in this community (Allan 1976). Classically are recognized three groups: Monogononta, Bdelloidea and Seisonacea. Monogononta and Bdelloidea have the largest number of species and occur predominantly in freshwater, while Seisonacea has only three marine species (Segers 2008). In aquatic ecosystems, many organisms can parasite rotifers, among them are the fungi species that obtain part or all of their nutrition by attacking and consuming them (Barron, 2004). Some species parasitize bdelloids rotifers specifically (Barron \& Szijarto 1984), while others affect different Monogononta rotifers.

Olpidium spp. are a holocarpic fungi belonging to Chytridiomycota (Kirk et al. 2008) that parasitize primarily freshwater algae, fungi, mosses, pollen, flowering plants and microscopic animals such as rotifers (Karling 1977). This endoparasitic genus produces zoosporangia which discharge zoospores via exit tubes that are plugged with mucus prior to zoospore release. Therefore, during the infection, the fungus digests the internal content of the host, while forms a thallus inside it where new zoospores can be produced and discharged, starting again the process (Barron 2004). Seven species of Olpidium have been reported to infect adults or eggs of rotifers and other invertebrates (Dick 2001), with O. gregarium most commonly reported (Glockling 1998). Until now, only two species, Olpidium granulatum and $O$. rotiferum, were cited parasitizing eggs and adult rotifers in Brazilian freshwaters in Amazonas and Rondônia States (Karling 1946).

\section{Materials and Methods}

In March 2009, rotifers samples were collected in 12 sampling spots along the central axis of Rio Grande Reservoir, São Bernardo do Campo, São Paulo State, Brazil. Sampling spot 1 is the furthest from the dam, while sampling spot 12 is the closest. Rotifers samples were collected in vertical hauls with a $68 \mu \mathrm{m}$ mesh net and posterior estimation of the water filtered volume. The organisms were narcotized with carbonated water and the samples were preserved with $4 \%$ formalin-sucrose solution. Rotifers were identified according to Koste (1978), Segers \& Dumont (1995) and Shiel \& Koste (1992), while the parasitic fungus was identified according to Sparrow Junior (1960), Karling (1977) and Glockling (1998). Sub-samples of the rotifers sample were counted in a Sedgwick-Rafter camber until 100 individuals of the most abundant species. Affected rotifers were considered the ones showing sporangium structures into the body. In the places where was observed the major number of affected organisms (sampling spots 10, 11 and 12), it was calculated the average percentage of affected individuals of each species in relation to the all affected individuals.

\section{Results and Discussion}

The parasitic fungus was identified as Olpidium gregarium (Nowak.) J. Schröt., species that belongs to the phylum Chytridiomycota, class Chytridiomycetes, Olpidiaceae family (Figure 1). This species seems to be the most common and widely distributed around the world (Karling 1946, Sparrow Junior 1960, Glockling 1998). However, in Brazil, this is the first report of this species, where only rotifers adults were affected. Therefore, despite this species can also affect rotifers eggs, it was not observed the occurrence of zoosporangia in eggs. Perhaps the sampling has been inefficient to evaluate this fact. It is also important to highlight that the organisms considered here as affected, does not reveal the real number of the affected rotifers, but the occurrence of the zoosporangium.
Moreover, during the zoosporangium development, the fungus uses the internal content of the host, killing it, thus, rotifers considered here as affected are, in fact, dead (Karling 1946).

The zoosporangia of the specimens observed were smooth, commonly oval or ellipsoidal, $16-30 \times 15-25 \mu \mathrm{m}$, usually numerous into the rotifers, with a short tube, sometimes long, to discharge hyaline zoospores; encysted zoospores measuring 2-3.5 $\mu \mathrm{m}$ diameter, with a single eccentric refractive globule; resting spores not observed.

Affected rotifers were found in all sampling spots in Rio Grande Reservoir and 14 out of 27 rotifers species were affected. The most abundant rotifers were Proales sp., Collotheca sp. and Polyarthra aff. vulgaris (Figure 2). Proales sp. and Polyarthra aff. vulgaris were the most affected taxa, however, Collotheca sp. was not affected at all (Table 1), indicating that $O$. gregarium affected preferentially some rotifers taxa and may have influenced the rotifers distribution along the reservoir gradient. It is not known why this preference for some hosts species occurs. Glockling (1998) mentioned that species of the genus Olpidium do not affect bdelloids rotifers. Therefore, this genus may affect the Monogononta, the only group isolated in this study. In Monogononta, one factor observed that can contribute to host preference is the body shape, since the most affected species had a body with similar length and width, while not affected species as Collotheca sp. have a slimmer body (length greater than width).

A clear gradient was observed in Rio Grande Reservoir, with rotifers density decreasing near the dam (Figure 3). The proportion of affected rotifers displayed an opposite pattern, increasing near the dam (Figure 3). Rotifers species abundance also varied in the reservoir, corroborating the reservoir spatial heterogeneity (Figure 2). These patterns of spatial heterogeneity in rotifers' abundance and in affected rotifers proportion bring evidences that the rotifers distribution in Rio Grande Reservoir is being affected by the parasitic fungus O. gregarium. Thomas et al. (2011) suggested that the evidences on rotifers' parasitism show that this interaction can greatly affect the density of rotifers populations, rotifers evolution and other interspecific interactions. However, there are few studies about the potential influence of parasites on rotifers populations. Further investigations are required to elucidate how $O$. gregarium affects the rotifers populations and, in this way, its role in the zooplankton community structure and dynamic.

The distribution pattern of O. gregarium in Rio Grande Reservoir is not clear. According to Meirinho (2010), a gradient of environmental conditions occurs along the central axis of the Rio Grande Reservoir, what forms compartments with distinct characteristics; this gradient is followed by the zooplankton community that also displays differences among compartments. Therefore, in the same way as occur with rotifers, the $O$. gregarium pattern may also be related to the physical,

Table 1. Most abundant rotifers taxa in the sampling spots where the parasitic chytrid fungus was more abundant (near the dam), and the respective proportion (\%) of affected individuals of each species in relation to all affected individuals (average data of the sampling spots 10, 11 and 12).

\begin{tabular}{lc}
\hline \multicolumn{1}{c}{ Rotifera species } & \% \\
\hline Anuraeopsis navicula Rousselet, 1910 & 1.7 \\
Collotheca sp. & 0 \\
Kellicottia bostoniensis (Rousselet, 1908) & 2.4 \\
Keratella tropica Apstein, 1907 & 12.1 \\
Polyarthra aff. vulgaris & 24.5 \\
Proales sp. & 31.9 \\
Trichocerca dixon-nuttalli (Jennings, 1903) & 0.8 \\
Other species & 26.6 \\
\hline
\end{tabular}


Meirinho, P.A. et al.
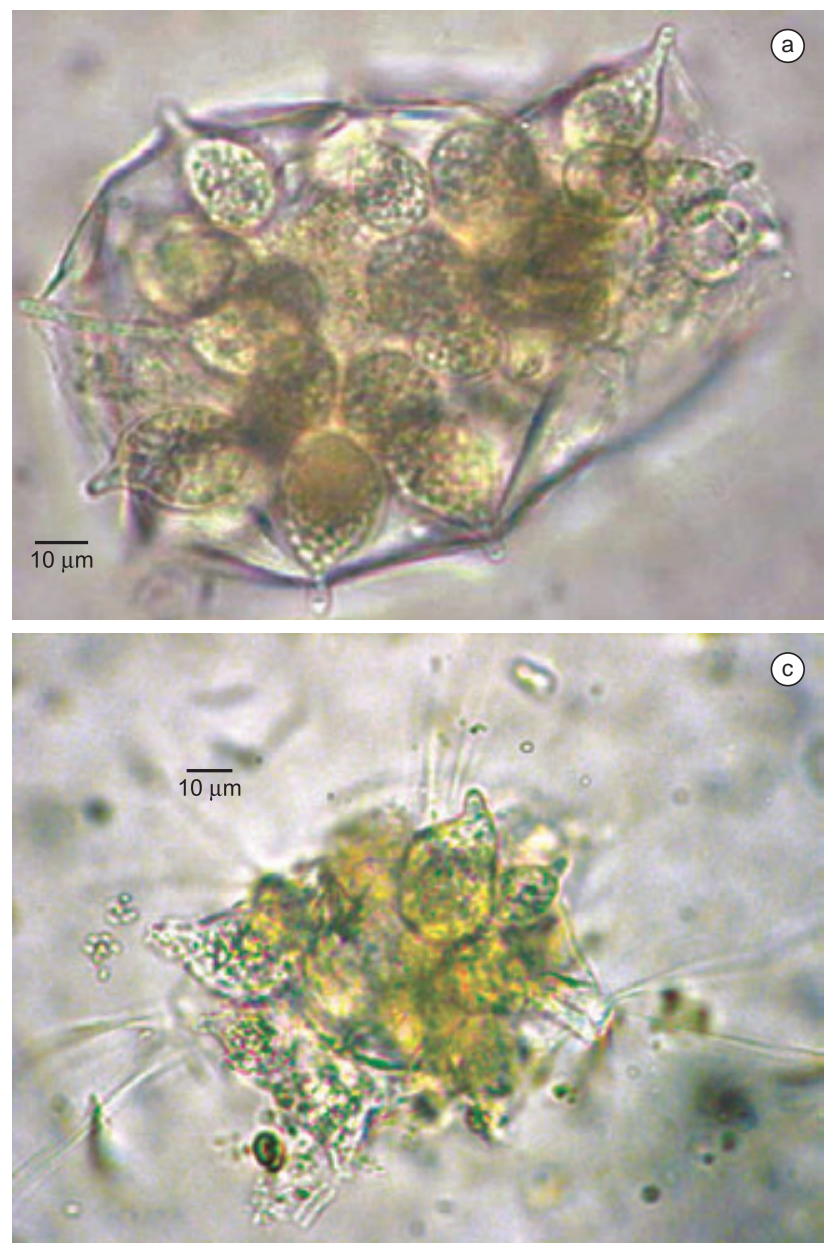
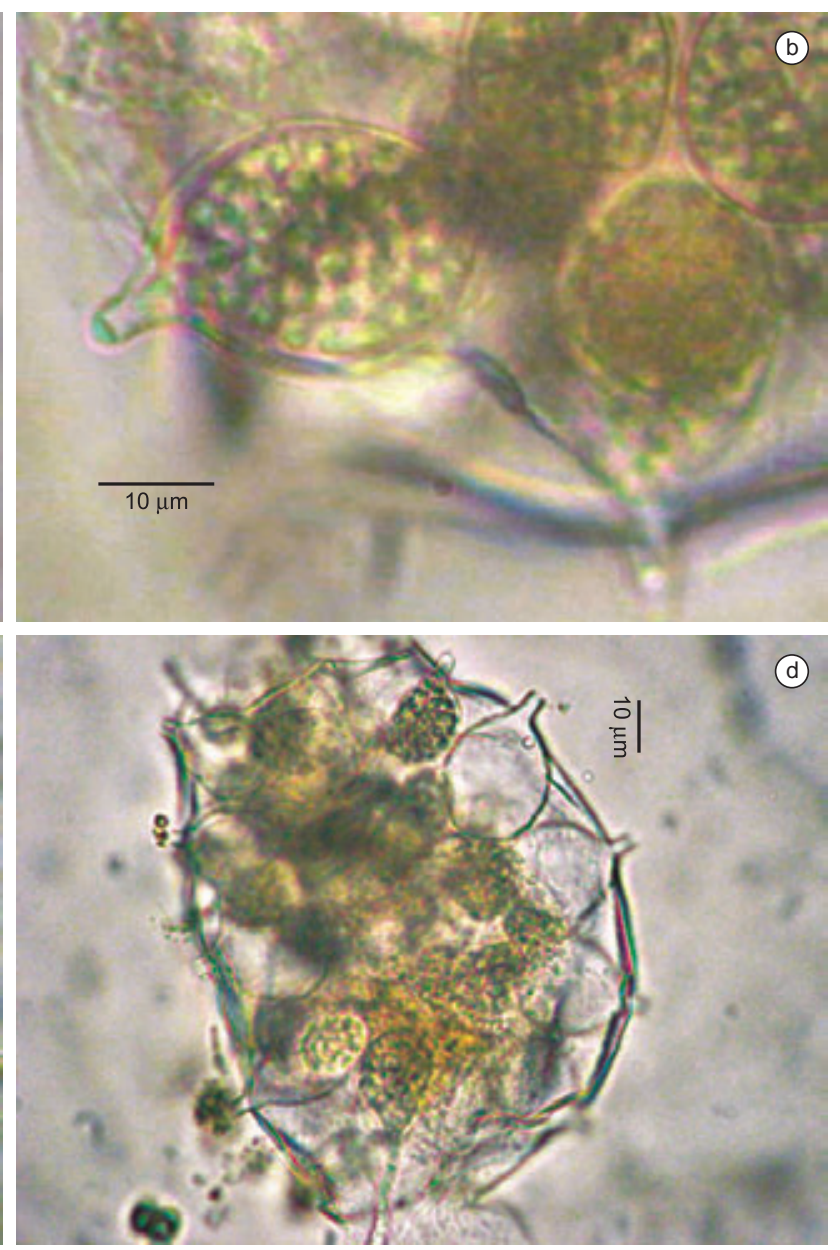

Figure 1. a) Proales sp. displaying Olpidium gregarium' zoosporangia. b) In detail, the zoosporangia structure. c) Polyarthra aff. vulgaris displaying zoosporangium with zoospores released. d) Proales sp. with empty zoosporangia.

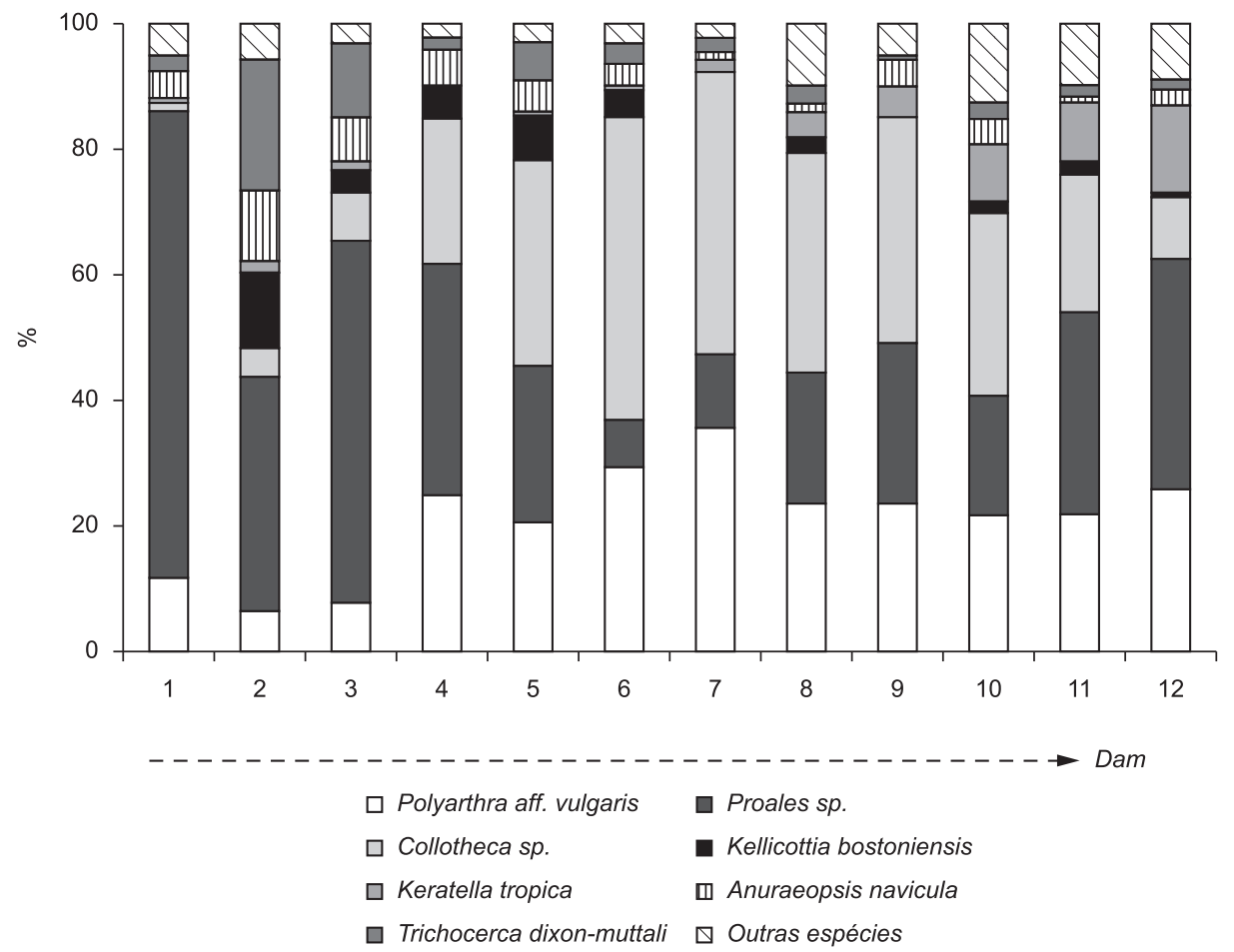

Figure 2. Relative abundance of rotifers' species along Rio Grande Reservoir central axis. Sampling spot 1 is the furthest from the dam, while sampling spot 12 is the closest. 


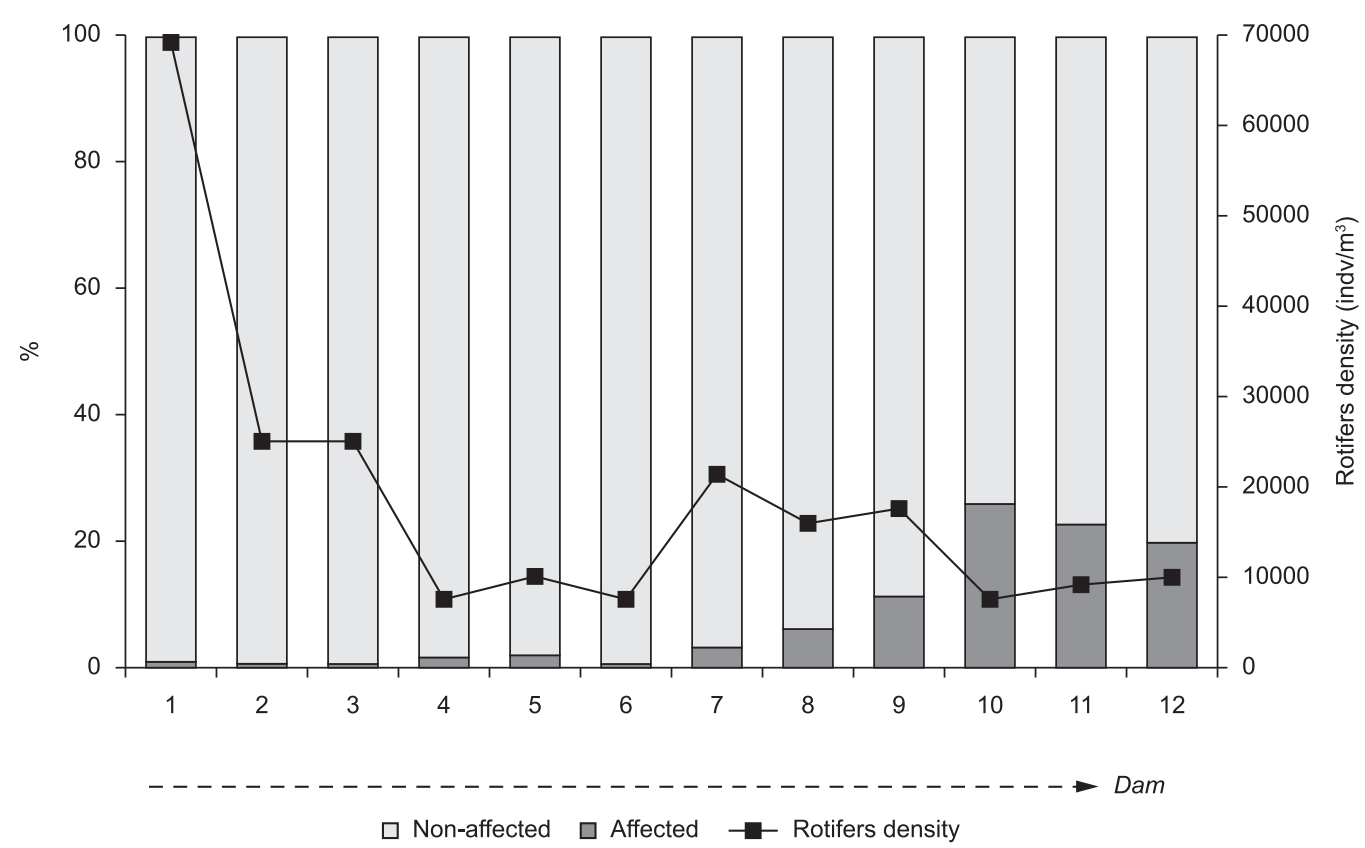

Figure 3. Proportion of affected and non-affected rotifers, and rotifers density along Rio Grande Reservoir central axis. Sampling spot 1 is the furthest from the dam, while sampling spot 12 is the closest.

chemical and biological characteristics of the reservoir compartments. For example, $O$. gregarium was more abundant near the dam, where the environment presents lake characteristics and is less eutrophic compared to the rest of the reservoir.

\section{Acknowledgments}

This project was supported by the Coordination for the Improvement of Higher Level (CAPES Master's scholarship for P. A. Meirinho).

\section{References}

ALLAN, J.D. 1976. Life history patterns in zooplankton. Amer. Nat. 110(971):165-180. http://dx.doi.org/10.1086/283056

BARRON, G.L. \& SZIJARTO, E. 1984. Fungal parasites of bdelloid rotifers: a new Phialophora. Mycologia 76(6):1107-1110. http://dx.doi. org/10.2307/3793026

BARRON, G.L. 2004. Fungal parasites and predators of rotifers, nematodes and other invertebrates. In Biodiversity of fungi, inventory and monitoring methods (G.M. Mueller, G.F. Bills \& M.S. Foster, eds.). Elsevier Academic Press, San Diego, p.435-450. http://dx.doi.org/10.1016/B978012509551-8/50022-2

DICK, M.W. 2001. Straminipilous fungi. Kluwer Academic Publishers, Dordrecht.

GLOCKLING, S.L. 1998. Isolation of a new species of rotifers-attacking Olpidium. Mycol. Res. 102(2): 206-208. http://dx.doi.org/10.1017/ S0953756297004693
KARLING, J.S. 1946. Brazilian chytrids. Additional parasites of rotifers and nematodes. Lloydia 9(1):1-12.

KARLING, J.S. 1977. Chytridiomycetarum iconographia. J. Cramer, Vaduz, New York.

KIRK, P.M., CANNON, P.F., MINTER, D.W. \& STALPERS, J.A. 2008. Dictionary of Fungi. 10th ed. CABI Bioscience, Wallingford.

KOSTE, W. 1978. Rotatoria, die Rädertiere Mitteleuropas: Überordnung Monogononta: ein Bestimmungswerk. Gebrüder Borntraeger, Berlin.

MEIRINHO, A.M. 2010. Compartimentalização da comunidade zooplanctônica em um reservatório tropical urbano eutrofizado (braço Rio Grande, Complexo Billings, SP). Dissertação de mestrado, Universidade de São Paulo, São Paulo.

SEGERS, H. \& DUMONT, H.J. 1995. 102+ rotifer species (Rotifera: Monogononta) in Broa Reservoir (SP., Brazil) on 26 August 1994, with the description of three new species. Hydrobiologia 316:183-197. http:// dx.doi.org/10.1007/BF00017436

SEGERS, H. 2008. Global diversity of rotifers (Rotifera) in freshwater. Hydrobiologia 595:49-59. http://dx.doi.org/10.1007/s10750-007-9003-7

SHIEL, R.J. \& KOSTE, W. 1992. Rotifera from australian inland waters VIII. Trichocercidae (Monogononta). T. Roy. Soc. South. Aust. 116(1):1-27.

SPARROW JUNIOR, F.K., 1960. Aquatic Phycomycetes. 2nd ed. University of Michigan Press, Ann Arbor.

THOMAS, S.H., HOUSLEY, J.M., REYNOLDS, A.N., PENCZYKOWSKI, R.M., KENLINE, K.H., HARDEGREE, N., SCHMIDT, S. \& DUFFY, M. 2011. The ecology and phylogeny of oomycete infections in Asplanchna rotifers. Freshwater Biol. 56:384-394. http://dx.doi. org/10.1111/j.1365-2427.2010.02505.x 